\title{
International Student Flows for University Education and the Bilateral \\ Market Integration of Australia
}

\author{
Byung S. MIN ${ }^{1)}$ and Rod FALVEY ${ }^{2)}$
}

\section{April 2017}

Study at a foreign university can be an important way of developing international human capital. We investigate factors affecting international student flows for higher education and their consequences for bilateral market integration in Australia. Estimation results demonstrate that income, cost competitiveness, migration network effects and other education pathways increase the demand for tertiary education. Our results show that university study, inter alia, is an important determinant of bilateral trade between Australia and the student's home country.

Key words: International Human Capital, Higher education, International students, Market integration, Australia

1). Griffith Business School,

Department of International Business and Asian Studies, Griffith University, 170, Kessels Rd, Nathan, Brisbane, Qld.

61737355248

b.min@griffith.edu.au

2). Bond Business School

Bond University, Gold Coast, QLD 4229

61755951298

rfalvey@bond.edu.au

We appreciate valuable comments from three anonymous reviewers and the editor (Hugo Horta) and three referees from ANZIBA2015, Peter Verhoeven, Adrian Cheung, Y.S. Choi and Ian Austin. We also thank seminar participants at the Korea Institute for International Economic Policy, Seoul in 2013 and participants at the Australia-New Zealand International Business Association (ANZIBA) 2015 conference at Melbourne Business School in 2015 and Global Conference on Business, Economics and Management, Rome in 2015. The usual disclaimer applies. 


\section{INTRODUCTION}

The reductions in policy barriers and international transportation and communication costs that have 'globalised' national markets for goods and capital have also encouraged and facilitated international student flows. UNESCO reports that the over 4.1 million tertiary students went abroad to study in 2014, an increase from 2 million in 2000. Of these 35\% were accommodated by the 3 leading English language hosts - USA (19\%); UK (10\%) and Australia (6\%). The increasing flows of international university students have prompted research exploring their causes and consequences. Work seeking the reasons or antecedents of students' choices, has relied on information from two sources - student surveys, typically designed and administered by the researcher; and published data, typically collected by government agencies. The former provide information on individuals, allowing a qualitative analysis of the factors motivating their choices. The latter is more aggregated, typically measuring the number of students flowing from a particular source country to universities in a particular host. While examination of this data cannot answer questions about the motivations of individuals per se, when supplemented by other data it does permit a quantitative analysis of the broad causes of these flows. This paper follows the latter approach and is a quantitative assessment of the factors underlying the demand for university education by international students in Australia.

Australia provides a useful study of the international demand for university education for several reasons. First, it is an important exporter of education services. About two-thirds of international university students are enrolled in the four major English-language countries, with Australia, following the USA and UK, the third most popular destination (Choudaha et al. 2013). Second, international students are 24 percent of total Australian tertiary students, which is by far the highest share among the English speaking countries. The finances of Australian universities therefore may be more dependent on international students than those of any other country. Finally, the export of education services has become increasingly important to the 
Australian economy, in terms of both export revenue (in 2015 education services were Australia’s third leading export earner) and export diversity (the leading two export earners were iron ore and coal).

But international higher education students may affect a country's trade in ways beyond direct education service exports. Research has established positive links between ethnic networks (migrants) and international trade (Rauch, 2001). Notwithstanding the reduction in formal barriers, international trade is still subject to significant informal barriers, related to the provision and interpretation of information and the international enforcement of contracts (Anderson and van Wincoop, 2004). The involvement of individuals of the same ethnicity or nationality with the appropriate 'international human capital' (familiarity with the language, law and customs in both locations) may reduce these barriers.

One important way in which individuals, and hence their eventual employers, can acquire international human capital is by studying abroad. International students can become familiar with host institutions, customs, culture, business practices and labour markets while studying, particularly if part-time work is permitted (Beine et al., 2015). This international human capital will have particular application to the host and source markets and could eventually be reflected in increased trade between them.

These observations motivate our two main goals in this paper. Firstly, we use a large panel dataset to investigate the determinants of international university study in Australia. As noted, international university education is an important source of international human capital, and Australia is an important provider of such study. The increasing dependence of Australian universities on the revenue from international students highlights the importance of understanding what factors determine this demand. More generally, by allowing for a nonlinear relationship between source country real income per capita and international student flows, we are able to explain conflicting results on the sign of this relationship in the literature. 
Our estimates also allow us to predict where growth in income per capita is likely to result in increased international student flows. We investigate migration network effects and their sensitivity to a common language and financial crises. Growing migrant stocks may indicate future flows in international students. The recent global financial crisis (GFC) allows us to test the sensitivity of international student flows to macro-economic conditions. Secondly, having identified the factors determining overseas study, we provide some preliminary evidence on the impact of international human capital acquired in this way on bilateral goods market integration between student source countries and Australia. It is useful to consider the two together because some factors that explain the decision of where to study overseas can be used as instruments in estimating the effects of past study on trade flows.

The remainder of this paper is as follows. The next section briefly describes the Australian education system and develops our main hypotheses to be tested. The following section presents our variables, the equations to be estimated and discusses our data. Our results and conclusions follow.

\section{RESEARCH CONTEXT AND HYPOTHESES}

\section{Australian higher education}

The international integration of higher education has increased rapidly in the last few decades. Table 1 shows undergraduate international student numbers in 2004 and 2012 for the three leading English language university systems (US, UK and Australia).

Table 1 International undergraduate enrolments and costs.

\begin{tabular}{|l|c|c|c|c|}
\hline & Year(s) & Australia & $\begin{array}{c}\text { United } \\
\text { Kingdom }\end{array}$ & United States \\
\hline $\begin{array}{l}\text { Number of International } \\
\text { undergraduate students }\end{array}$ & 2004 & 120,500 & 114,800 & 178,700 \\
& 2012 & 192,600 & 198,700 & 244,800 \\
\hline
\end{tabular}




\begin{tabular}{|l|c|c|c|c|}
\hline $\begin{array}{l}\text { International undergraduate students } \\
\text { as a share of total international } \\
\text { enrolment (\%) }\end{array}$ & 2004 & $\begin{array}{l}60 \\
60\end{array}$ & $\begin{array}{l}38 \\
46\end{array}$ & 40 \\
\hline $\begin{array}{l}\text { International undergraduate students } \\
\text { as a share of total national } \\
\text { undergraduate enrolment (\%) }\end{array}$ & 2004 & $\begin{array}{l}19 \\
24\end{array}$ & $\begin{array}{c}9 \\
13\end{array}$ & 2 \\
\hline Annual Fees (\$US) & 2013 & 25,375 & 19,291 & 25,226 \\
\hline Annual Cost of Living (\$US) & 2013 & 13,140 & 11,034 & 10,479 \\
\hline Annual Total Cost (\$US) & 2013 & 38,516 & 30,325 & 35,705 \\
\hline $\begin{array}{l}\text { Number of universities in Shanghai } \\
\text { top 100 }\end{array}$ & 2013 & 6 & 9 & 43 \\
\hline $\begin{array}{l}\text { Number of universities in THS top } \\
100\end{array}$ & 2013 & 5 & 9 & 52 \\
\hline Number of universities in QS top 100 & 2013 & 7 & 18 & 30 \\
\hline
\end{tabular}

Sources: Rows 1-3 Choudaha et.al. (2013); rows 4-6 HSBC News Release August 13, 2013; row 7 Academic Ranking of World Universities (Shanghai Jiao Tong University); row 8 QS World University Rankings (Quacquarelli Symonds); and row 9 Times Higher Education World University Rankings.

Australia has 41 universities, 38 of which are Government funded. A standard bachelor's degree requires three years of study, with honours taking an additional year. Students can also pursue graduate and vocational graduate certificates and diplomas over shorter periods. International students can enroll directly into higher education or through alternative pathways such as (secondary) SCHOOLS, English Language Intensive Courses for Overseas Students (ELICOS), or vocational education and training (VET). Since VET can be a pathway to university study or an end in itself, VET study may be a substitute or complement for tertiary education.

\section{International student flows for higher education in Australia}

As noted earlier, the literature provides both quantitative and qualitative analyses of the factors determining the demand for higher education from international students. The qualitative approach uses survey data and is particularly suited to investigating factors at the individual (person or institution) level. Such surveys include Mazzarol and Soutar, (2002) for students in China, India, Indonesia and Taiwan; Shanka et al. (2006) for foreign students at one Australian university; Li and Bray, (2007) for Chinese students studying in Hong Kong and Macau; Pyvis and Chapman (2007) for students at the Malaysian campus of one Australian university; Lu et al. (2009) and Gong and Huybers (2015) for Chinese students interested in studying abroad; 
Cantwell et al. (2009) for international students in Mexico; Ahmad and Buchanan (2015) for students at international branch campuses in Malaysia; Ahmad and Hussain (2015) for students at two universities in the UAE; and Pedro and Franco (2016) for foreign students at one Portuguese university. These studies have identified the key attractors for institutions including: academic reputation, variety of courses offered, quality of education, campus safety and location and costs. They also find that the opinions of family (who are often bearing the cost) and friends are important for the student (Shanka et al., 2006).

The quantitative approach draws on published statistics and relies on regression analysis to identify the significant factors. Because the data is typically aggregated across individuals (persons and institutions) it is best suited to identifying those factors important for national policy making. Studies adopting this approach include Agarwal and Winkler (1985) and, McMahon (1992) for the USA; Lee and Tan (1984) for students from developing countries; Naidoo (2007), Soo and Elliott (2010) and Zheng (2014) for the UK; Gonzalez et al. (2011) for European students on the Erasmus program; Beine et al. (2011) for the OECD countries; Bessey (2012) for Germany; and Wei (2013) and Perkins and Neumayer (2014) for bilateral flows of international students in general.

This literature identifies social, economic and political characteristics, typical dichotomised as 'push' or 'pull' factors, that influence student flows. Push factors refer to the source country characteristics and pull factors to host country characteristics. Since we are confined to aggregate (source and host country) data several factors important to the individual student decision are unavailable. These include, in particular, information on students' resources, students' perceptions of relative course quality, students' local opportunities and their migration intentions. This makes our analysis complementary to the work based on student surveys. 
International study will be attractive as a human capital investment if its return is higher than the domestic alternative. Typically the costs of international study are higher than domestic study, but so are the benefits from studying at higher ranked and better recognized institutions. In addition, acquiring a foreign qualification, particularly in a foreign language, can provide a credible signal of an individual's capabilities. Given the well-known failures in the human capital market, funding foreign study is likely to depend on the students' family resources (Carneiro and Heckman, 2002; Keane, 2002). Since we cannot directly observe 'family wealth', we, like the literature, fall back on 'real income per capita' as an indicator of the 'average' ability to finance international study in each source country.

There are at least two drawbacks to this, however. First, richer countries are also likely to fund higher quality domestic tertiary institutions, thereby reducing the gains from international study (McMahon, 1992). Second, differences in income per capita are often thought to capture the incentive for international migration. A higher per capita income in the source country will then reduce the incentive for students to use university study in Australia as a pathway to migration (Perkins and Neumayer, 2014).

In combination, these potentially conflicting influences imply ambiguity in the relationship between source income per capita and international student flows. We therefore explicitly allow for a nonlinear relationship:

H1: There is a nonlinear relationship between a source country's real income per capita and the number of its students undertaking higher education in Australia.

International students are usually full-fee paying, face international travelling costs, and often face living expenses greater than at home. The range of estimated fees and costs of living for international students in the three major host countries in 2013 presented in Table 1 is notable. Other things equal, we expect that higher costs in Australia, relative to costs in the alternative English language hosts, will reduce international student flows to Australia. Hence: 
H2: Higher costs of international study, relative to those in the UK and US will have a negative impact on international student flows for higher education in Australia.

Existing networks of former students and migrants motivate and assist students to study overseas (Dreher and Poutvaara, 2005; Perkins and Neumayer, 2014; Pedro and Franco, 2016). The size of the migrant community from a student's source country in Australia can be important in this respect. The size of the migrant community may also reflect the 'intention to migrate' motivation for international study. Existing migrant-networks may be more valuable for non-English speakers. Therefore:

H3A: We expect a positive relationship between the source migrant stock and the international student flows for higher education in Australia.

H3B: This positive effect will be stronger for students from non-English speaking sources.

For higher education study, compatriots who have completed one of the other education pathways, will have a positive direct effect (when the same students are involved) and can have positive indirect effect (when they are other family members, friends or acquaintances) on international student flows. Successful graduation from an Australian school is a positive signal to both universities and students, and should therefore increase the demand for higher education. Intensive English learning programs have become a recruitment pathway for higher education. However, VET can be a substitute or complement for higher education, as noted earlier ${ }^{1}$. Our two hypotheses here are:

H4A: Previous enrolment in the SCHOOL and ELICOS pathways will have a positive impact on international student flows for higher education in Australia.

\footnotetext{
${ }^{1}$ Australian Department of Education (2014) reports that 36\% of the students who completed ELICOS in 2012 moved eventually to higher education. The corresponding figure for SCHOOL was $38 \%$. Of the international students entering higher education in Australia in 2013, only 10\% had previously completed a VET course. These figures reflect quite diverse patterns for students from different sources, however.
} 
H4B: Previous enrolment in the VET pathway may increase or reduce international student flows for higher education in Australia.

These are our hypotheses relating to international student flows to Australian universities. ${ }^{2}$

\section{The impact of higher education on bilateral goods market integration:}

There is an established literature, in both economics and international business, on the links between migration networks and international trade (Parsons 2011; Ahlstrom and Bruton 2006). But Aleksynska and Peri (2012) report that only highly educated immigrants in business network occupations enhance trade, a qualification which suggests that the international human capital acquired through higher education can reduce the transactions costs noted earlier. Those international students who return home once their studies are completed may also contribute towards increased trade with their former host country. Hence:

H5: The international human capital obtained by international tertiary education increases the host country's bilateral market integration with the source countries.

In summary two estimations are undertaken here. The first identifies factors affecting international student flows for higher education in Australia. The second measures the impact of prior tertiary education on bilateral market integration through trade. Because the response variable of the first stage is an endogenous variable at the second stage we use instrumental variable estimation in the second stage.

\section{METHODS AND DATA}

\footnotetext{
${ }^{2}$ An additional hypothesis that we would like to have included relates to the perceived quality of Australian universities relative to their competitors. To test such a hypothesis at this aggregated level requires an index of the relative quality of national university systems. Existing rankings (see Table 1 for example) relate to individual institutions not university systems, and indices based on these rankings produced mixed results in our estimations. Fortunately their inclusion or exclusion in the regressions had little impact on the other coefficient estimates. It seems unlikely that perceptions of the relative quality of the Australian university system would have changed much over our sample period in any case.
} 


\section{International student flows for higher education: Reduced form estimation at the first stage}

Equation (1) shows the reduced-form equation explaining the international student flows for higher education in Australia:

$$
\begin{gathered}
\mathrm{Y}_{\mathrm{it}}=\text { constant }+\beta_{1} R G D P_{i t}+\beta_{2} \text { RGDP }_{i t}^{2}+\beta_{3} \text { STUDYCOST }_{i t}+ \\
\beta_{4} \text { MIGRATION }_{i t-1}+\boldsymbol{\beta}_{\mathbf{5}} \text { PATHW AYS }_{i t-1}+\boldsymbol{\beta}_{\mathbf{6}} \text { OTHERS }_{i t}+\varepsilon_{\mathrm{it}}
\end{gathered}
$$

Here $\mathrm{Y}_{\text {it }}$ is the number of international students from country $i$ enrolled at Australian universities in year t. ${ }^{3}$ To reduce heterogeneity we scale student numbers by the source country's population aged between 15 and 64 (in millions). In estimation, we also take the logarithm of this dependent variable to mitigate the skewness problem. Data on population is from the World Bank’s World Development Indicators. Data from 2002 to 2011 for all of the student pathways is available from Australian Education International (AEI) http://www.aei.gov.au/research/International-Student-Data/Pages/default.aspx. ${ }^{4}$ We found that this data had a number of extreme values, and therefore winsorized all data in the upper and lower 1 percent level.

$R G D P$ and $R G D P^{2}$ are real GDP per capita and GDP per capita squared respectively in source country $i$ in year $t$. H1 suggests that the coefficients on $R G D P$ and $R G D P^{2}$ may differ in sign. Purchasing power parity adjusted GDP per capita was obtained from the World Bank.

STUDYCOST refers to the relative cost of living and studying in Australia compared to its main competitors, calculated as the ratio of the average of the fees and cost of living indexes in the US and the UK to the fees and cost of living index in Australia. Annual data on the costs of higher education in different locations are unavailable, but we do have estimates for the

\footnotetext{
${ }^{3}$ Estimates based on commencements are similar and are also available.

${ }^{4}$ We exclude the data before 2002 because significant changes in the methodology used for International Enrolments Data caused a break in the time series in that year. Likewise in 2011 the Australian Government implemented significant policy changes following a review of student visa requirements and procedures. A student's nationality is based on citizenship. Overseas students on Australian funded scholarships or sponsorships, or students undertaking study while holding a tourist or other temporary entry visas are excluded, as are New Zealand students as they do not require a student visa to study in Australia.
} 
'Annual cost of studying abroad for international students (in \$US)' in 2013 from HSBC as reported in Table 1. This data is broken down into Fees and Cost of Living (CoL) components, and we have used these observations to construct time series estimates for Australia, the US and the UK over our sample period. To do this we deflate the Fees by the education cost component of the consumer price index, and the CoL by the full consumer price index, ${ }^{5}$ and also take into account changes in exchange rates. The resulting cost estimates are shown in Table A1 in the Appendix. These numbers indicate significant changes in relative costs over our sample period. From 2002 to 2011, the annual cost of studying in Australia increased by $182 \%$, compared with $70 \%$ in the UK and $49 \%$ in the US. The major source of the increase in Australia’s relative costs was its exchange rate appreciation. In \$A terms the annual cost of studying increased by $48 \%$, roughly equivalent to that in the US ${ }^{6}$.

MIGRATION is the logarithm of the number of migrants from source country $i$ in Australia in year $t$ scaled by the total population in source country $i$ (in millions). The network hypothesis implies a positive coefficient on MIGRATION. Immigration data is from the Department of Immigration and Citizenship, Australia (http://www.immi.gov.au/media/statistics/).

PATHWAYS is a vector of the number of students from source country $i$ in SCHOOL, ELICOS and VET in year t-1. This data is also scaled by the source country's population aged between 15 and 64 (in million). Hypothesis 4A suggests positive estimated coefficients on SCHOOL and ELICOS, while 4B suggests the coefficient on VET could have either sign.

OTHERS is a vector of three separate indicator variables. Firstly, the Global Financial Crisis indicator (GFC0809) is set equal to one in 2008 and 2009 and zero otherwise. Secondly, Lowincome is equal to one for those countries whose RGDP is lower than the median value

\footnotetext{
${ }^{5}$ From Australian Bureau of Statistics, US Bureau of Labor Statistics and UK Office of National Statistics, respectively.

${ }^{6}$ The corresponding increase in UK costs measured in $£ U K$ is $58 \%$.
} 
and zero otherwise. Finally, COMLANG is equal to one for countries with English as an official language and zero otherwise. These variables are individually included or excluded from the regressions that follow depending on the hypotheses under consideration. Country-fixed effects are included in most estimations to mitigate the biases from omitted variables at the countrylevel. Their inclusion means that other time-invariant variables (e.g. distance) cannot also be included.

The impact of international education on trade: instrumental variable estimation for the second stage

The estimation equation for the impact of prior international student flows $\left(Y_{i t-5}\right)$ on Australian trade with the source country is given by (2). Considering that a standard bachelor's degree in Australia requires at least three years of study as described above, we assume five years of lags are required before any effects of student international flows are reflected in a bilateral trade benefits. This will allow the relevant individuals to have had 2 to 4 years of employment. ${ }^{7}$

$E X P_{i t c}\left(I M P_{i t c}\right)$ is the share of source country $i$ in Australia's exports (imports) at time t, where $c$ stands for total, primary or manufacturing exports (imports) respectively.

$$
E X P_{i t c}=\alpha_{0}+\delta_{1} \widehat{Y}_{i t-5}+\boldsymbol{\delta}_{2} \text { Othersit }+\zeta_{i t}
$$

Trade data are from Australia’s Merchandise Exports and Imports published by the Department of Foreign Affairs and Trade (http://www.dfat.gov.au/publications/stats-pubs/pivottables.html). The control variables (Others) are standard for a bilateral trade gravity equation (Rose, 2007; Disdier and Head, 2008): Comlang, is as above; ldistance is the log of physical distance from Australia; lareap is the log of the area of the source country; and colony denotes if a source country has been a British colony. Country fixed effects capture time-invariant

\footnotetext{
${ }^{7}$ The limited time dimension of our sample precludes us from testing for lag length etc., so in this dimension at least our results should be viewed as preliminary.
} 
(bilateral) trade resisting or promoting forces. We use instrumental variable methods for estimation because our main covariate, international students in Australia, is endogenous as identified by equation (1). The excluded instruments are mainly the control variables in equation (1). In estimation, we used the generalised method of moments (GMM). ${ }^{8}$

Table 2 reports summary statistics for our variables. The mean (563.1) of the scaled enrolment data is substantially greater than median (102.4), which indicates a distribution skewed toward the right-hand tail. Taking the logarithm substantially reduced this skewness as the mean [4.74] and median [4.67] become similar. For the same reason, we take the logarithm of the three (scaled) pathways, GDP per capita, and the migration stock. Table 2 shows that higher education is more important than the three pathways combined in terms of enrolments.

\section{RESULTS}

\section{Determinants of study in Australia}

Table 3 reports results for equation (1). In addition to the baseline model [1], models [2] and [3] include fixed effects as described in the note below the table. The results support our main hypotheses. An F-test of the joint null of both $R G D P$ and $R G D P^{2}$ was rejected at the 1 percent level for all our estimations. The coefficients on $R G D P$ and $R G D P^{2}$ are significant and opposite in sign (negative on $R G D P$ and positive on $R G D P^{2}$ ), indicating a quadratic relationship consistent with our hypothesis H1. The income elasticity of international student flows for tertiary education in Australia depends on the source income level. Given this nonlinear relationship one can see how previous work which simply included GDP per capita could

\footnotetext{
${ }^{8}$ The GMM, one of the most widely used methods of estimation, provides a solution to endogeneity problems (Wooldridge, 2010).
} 
produce a positive, negative or insignificant coefficient estimate depending on the sample of source countries. $^{9}$

Table 2 Summary statistics

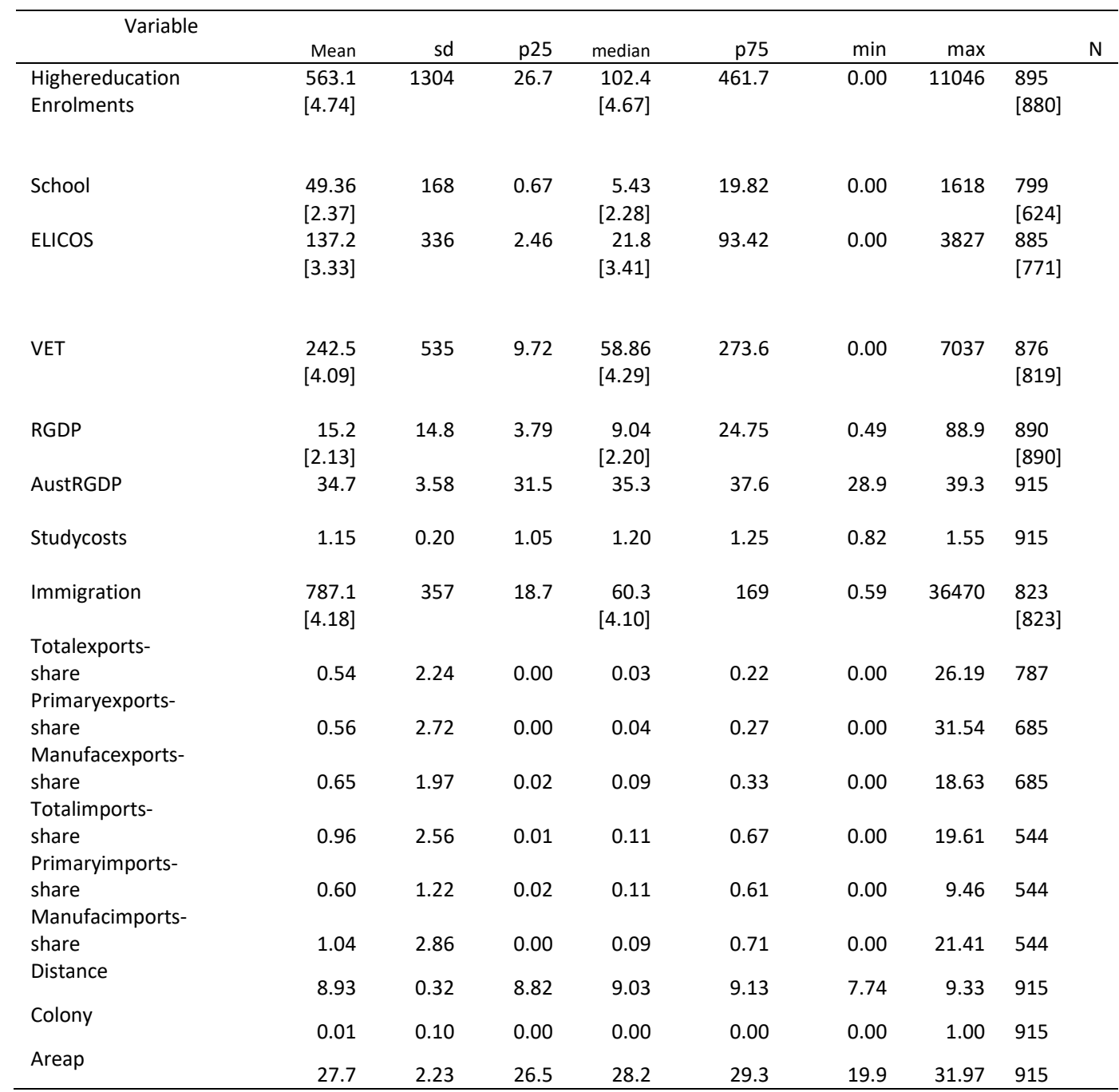

Notes: Higher education includes off-shore students. Figures in [ ] are means of log values. Immigration stock is calculated by accumulation of yearly migration using baseline data in year 2000. All figures are winsorized in the top and bottom 1 percent level.

The preferred specification [3], as suggested by the BIC statistics, indicates that the income elasticity of enrolment from a poor country (i.e., per capita GDP $<\$ 8,200$ ) will fall as income rises, while this income elasticity from a rich country will rise with income. For example, a one percent increase in income in a country where GDP per capita is $\$ 20,000(\$ 2,000)$ will lead to

\footnotetext{
${ }^{9}$ Zheng (2014) finds GDP per capita is negative and significant for non-OECD source countries and positive and significant for OECD source countries, consistent with our estimated nonlinear relationship.
} 
an increase (decrease) in international student flows for tertiary education in Australia by 1 (1.3) percent.

Table 3 Determinants of international higher education enrolment in Australia

\begin{tabular}{llll}
\hline & \multicolumn{3}{l}{ Enrolment } \\
\cline { 2 - 4 } RGDP & {$[1]$} & {$[2]$} & {$[3]$} \\
& & & \\
RGDP & & & \\
& $-0.74^{* * *}$ & $-0.85^{* * *}$ & $-0.86^{* * *}$ \\
STUDYCOST & {$[0.12]$} & {$[0.13]$} & {$[0.13]$} \\
& $0.15^{* * *}$ & $0.21^{* * *}$ & $0.21^{* * *}$ \\
MIGRATION & {$[0.03]$} & {$[0.04]$} & {$[0.04]$} \\
& $1.12^{* * *}$ & $1.25^{* * *}$ & $1.25^{* * *}$ \\
SCHOOL & {$[0.26]$} & {$[0.26]$} & {$[0.26]$} \\
& $0.25^{* * *}$ & $0.25^{* * *}$ & $0.26^{* * *}$ \\
ELICOS & {$[0.04]$} & {$[0.04]$} & {$[0.04]$} \\
& $0.11^{* * *}$ & $0.09^{* * *}$ & $0.07^{* *}$ \\
VET & {$[0.03]$} & {$[0.03]$} & {$[0.03]$} \\
& $0.32^{* * *}$ & $0.33^{* * *}$ & $0.34^{* * *}$ \\
Constant & {$[0.03]$} & {$[0.04]$} & {$[0.03]$} \\
& $0.25^{* * *}$ & $0.26^{* * *}$ & $0.27^{* * *}$ \\
& {$[0.04]$} & {$[0.04]$} & {$[0.04]$} \\
$\bar{R}^{2}$ & $1.58^{* * *}$ & $0.68^{*}$ & 0.57 \\
$\mathrm{~N}$ & {$[0.38]$} & {$[0.41]$} & {$[0.40]$} \\
BIC & & & \\
\hline Not Fig & 0.72 & 0.72 & 0.73 \\
& 494 & 485 & 485 \\
& 1238.6 & 1224.8 & 1208.3 \\
\hline
\end{tabular}

Note: Figures in [ ] show heteroskedacity-robust standard errors. Country-fixed effects are included in model [2]. Country-fixed effects and year-country-fixed effects are included in model [3]. $\mathrm{N}$ refers to country (93) by year. BIC refers to Bayesian Information Criterion.

The estimated coefficients on STUDYCOST, are all positive and significant at the 1 percent level, consistent with hypothesis H2. The appreciation of \$A will have reduced students international flows through its effects on relative costs.

The estimates in Table 3 indicate significant migrant-network effects, consistent with hypothesis H3 and the results of Perkins and Neumayer (2014). Immigrants indirectly increase Australian exports of tertiary education services.

The results confirm H4A that students use both SCHOOL and English-language study (ELICOS) as a pathway to tertiary education in Australia. VET proves to be a complement for 
higher education. In the preferred specification [3], the elasticity of $S C H O O L$ enrolment is less than that of ELICOS and VET.

\section{The impact of study in Australia on bilateral trade:}

Table 4 reports separate GMM estimation of equation (2) for total, primary and manufacturing exports. Based on our results in Table 3, we used the six period lag of STUDYCOST, MIGRATION, ELICOS, VET and SCHOOL as the excluded instruments. ${ }^{10}$ $R G D P$ was used as an independent variable.

Five-period lagged Enrolment, as instrumented, is positive and significant irrespective of specification and type of exports. This is supportive for H5. The estimated signs on the control variables (Areap, Colony, Comlang, Distance) meet standard predictions.

We transformed the estimated coefficients on enrolments, which represent semielasticities, into elasticities using mean trade values to make them comparable across equations. The enrolment elasticity of Primary exports in [5] is $0.38(=0.21 / 0.56)$, which is larger than that on Manufactured exports in [6] $(0.22=0.14 / 0.65)$. International human capital acquired through tertiary education has a positive effect on both export categories, but the impact on primary exports is 73 percent larger than that on manufactured exports.

The bottom panel of Table 4 provides information on the first-stage estimation. The pvalues of both $F$-statistics and the sizeable $\bar{R}^{2}$ and partial $\bar{R}^{2}$ support our specifications. ${ }^{11}$

Table 4 Instrumental variable estimation of the impact of international human capital on Australian exports

\footnotetext{
10 2SLS estimation show qualitatively similar results. The instruments are correlated with the instrumented variable (as confirmed in Table 3) but are uncorrelated with the dependent variables in Table 4. Statistics of pairwise Pearson correlations between the selected instruments and the dependent variable in equation (2) are less than 1 percent (not reported).

${ }^{11}$ The robustness of the instrumental variable estimations was checked by re-estimated using different sets of instruments. Similar results were obtained (available on request).
} 


\begin{tabular}{|c|c|c|c|c|c|c|}
\hline & $\begin{array}{l}{[1]} \\
\text { Total } \\
\text { Exports- } \\
\text { share }\end{array}$ & $\begin{array}{l}\text { [2] } \\
\text { Primary } \\
\text { exports- } \\
\text { share }\end{array}$ & $\begin{array}{l}{[3]} \\
\text { Manufac } \\
\text { exports- } \\
\text { share }\end{array}$ & $\begin{array}{l}{[4]} \\
\text { Total } \\
\text { Exports- } \\
\text { share }\end{array}$ & $\begin{array}{l}{[5]} \\
\text { Primary } \\
\text { exports- } \\
\text { share }\end{array}$ & $\begin{array}{l}{[6]} \\
\text { Manufac } \\
\text { exports- } \\
\text { share }\end{array}$ \\
\hline \multirow[t]{2}{*}{ Enrolment (lagged 5 years) } & $0.72^{* * *}$ & $0.49 * * *$ & $0.75^{* * *}$ & $0.30^{* * *}$ & $0.21 * *$ & $0.14^{* *}$ \\
\hline & {$[0.13]$} & {$[0.11]$} & {$[0.10]$} & {$[0.11]$} & {$[0.10]$} & {$[0.06]$} \\
\hline \multirow[t]{2}{*}{ Areap } & $0.54^{* * *}$ & $0.34 * * *$ & $0.49 * * *$ & $0.49 * * *$ & $0.36^{* * *}$ & $0.57^{* * *}$ \\
\hline & {$[0.13]$} & {$[0.11]$} & {$[0.09]$} & {$[0.11]$} & {$[0.10]$} & {$[0.09]$} \\
\hline \multirow[t]{2}{*}{ RGDP } & $0.32 * * *$ & $0.15^{*}$ & $0.46^{* * *}$ & $0.44^{* * *}$ & $0.36^{* * *}$ & $0.88^{* * *}$ \\
\hline & {$[0.12]$} & {$[0.09]$} & {$[0.09]$} & {$[0.10]$} & {$[0.10]$} & {$[0.10]$} \\
\hline \multirow[t]{2}{*}{ Colony } & & & & $2.60^{* * *}$ & 0.56 & 0.80 \\
\hline & & & & {$[0.58]$} & {$[0.35]$} & {$[0.64]$} \\
\hline \multirow[t]{2}{*}{ Comlang } & & & & $0.91 * * *$ & $0.60^{*}$ & $1.21^{* * *}$ \\
\hline & & & & {$[0.32]$} & {$[0.36]$} & {$[0.28]$} \\
\hline \multirow[t]{2}{*}{ Distance } & & & & $-1.31 * * *$ & $-1.17 * * *$ & $-3.13^{* * *}$ \\
\hline & & & & {$[0.47]$} & {$[0.57]$} & {$[0.35]$} \\
\hline $\begin{array}{l}\text { F-test ( } p \text {-value) for RGDP } \\
\text { and RGDP² }\end{array}$ & $0.00 * * *$ & $0.02 * *$ & $0.00^{* * *}$ & $0.00 * * *$ & $0.00 * * *$ & $0.00^{* * *}$ \\
\hline $\bar{R}^{2}$ & 0.09 & 0.02 & 0.20 & 0.11 & 0.03 & 0.47 \\
\hline $\mathrm{N}$ & 295 & 284 & 284 & 295 & 284 & 284 \\
\hline \multicolumn{7}{|l|}{ First-stage estimation } \\
\hline $\bar{R}^{2}$ & 0.77 & 0.77 & 0.77 & 0.77 & 0.77 & 0.77 \\
\hline Partial $\bar{R}^{2}$ & 0.49 & 0.49 & 0.49 & 0.51 & 0.51 & 0.51 \\
\hline $\begin{array}{l}\text { F-value } \\
\text { (p-value) }\end{array}$ & $\begin{array}{l}50.12 \\
(0.00)\end{array}$ & $\begin{array}{l}50.12 \\
(0.00)\end{array}$ & $\begin{array}{l}50.13 \\
(0.00)\end{array}$ & $\begin{array}{l}53.43 \\
(0.00)\end{array}$ & $\begin{array}{l}53.43 \\
(0.00)\end{array}$ & $\begin{array}{l}53.43 \\
(0.00)\end{array}$ \\
\hline Excluded instruments & \multicolumn{6}{|c|}{4 Lag of STUDYCOST, MIGRATION, ELICOS, VET, SCHOOL } \\
\hline
\end{tabular}

Table 5 reports estimates of the same equations for shares of Australian imports. Overall, the results are similar to those in Table 4, with the main exception being that comlang has no significant effect on the total imports share. But this reflects a significant positive effect on manufacturing imports matched by a significant negative effect on primary imports. While a stronger (positive) common language effect for manufacturing imports is plausible given that manufactures involve sophisticated differentiated products, the negative effect for primary imports is somewhat counter intuitive. We therefore re-estimated our equations omitting comlang in [4]-[6]. The estimated coefficients on Enrolment are slightly decreased.

Table 5 Instrumental variable estimation of the impact of international human capital on Australian imports 


\begin{tabular}{|c|c|c|c|c|c|c|}
\hline & $\begin{array}{l}{[1]} \\
\text { Total } \\
\text { imports- } \\
\text { share }\end{array}$ & $\begin{array}{l}{[2]} \\
\text { Primary } \\
\text { imports- } \\
\text { share }\end{array}$ & $\begin{array}{l}{[3]} \\
\text { Manufac } \\
\text { imports- } \\
\text { share }\end{array}$ & $\begin{array}{l}{[4]} \\
\text { Total } \\
\text { imports- } \\
\text { share }\end{array}$ & $\begin{array}{l}{[5]} \\
\text { Primary } \\
\text { imports- } \\
\text { share }\end{array}$ & $\begin{array}{l}{[6]} \\
\text { Manufac } \\
\text { imports- } \\
\text { share }\end{array}$ \\
\hline \multirow[t]{2}{*}{ Enrolment (lagged 5 years) } & $0.50^{* * *}$ & $0.25^{*}$ & $0.53^{* * *}$ & $0.45^{* * *}$ & $0.21^{*}$ & $0.48^{* * *}$ \\
\hline & {$[0.15]$} & {$[0.14]$} & {$[0.16]$} & {$[0.13]$} & {$[0.13]$} & {$[0.13]$} \\
\hline \multirow[t]{2}{*}{ Areap } & $0.52^{* * *}$ & $0.64 * * *$ & $0.49 * * *$ & $0.52 * * *$ & $0.53^{* * *}$ & $0.45^{* * *}$ \\
\hline & {$[0.16]$} & [0.12] & {$[0.13]$} & {$[0.16]$} & {$[0.10]$} & {$[0.13]$} \\
\hline \multirow[t]{2}{*}{ AustRGDP } & -2.01 & -5.01 & -1.44 & -1.54 & -4.94 & -1.36 \\
\hline & {$[10.10]$} & [11.14] & {$[12.82]$} & {$[10.86]$} & {$[10.56]$} & [12.96] \\
\hline \multirow[t]{2}{*}{ Colony } & -0.45 & $0.78^{* *}$ & -0.93 & 0.02 & $0.49 * *$ & -0.09 \\
\hline & {$[0.75]$} & [0.39] & {$[0.80]$} & {$[0.53]$} & {$[0.23]$} & {$[0.53]$} \\
\hline \multirow[t]{2}{*}{ Comlang } & 0.00 & $-0.01 * * *$ & 0.00 & & & \\
\hline & {$[0.00]$} & {$[0.00]$} & {$[0.00]$} & & & \\
\hline \multirow[t]{2}{*}{ Distance } & $-0.94 * * *$ & $-3.30 * * *$ & $-0.57^{*}$ & $-1.20 * * *$ & $-3.97 * * *$ & $-0.52 *$ \\
\hline & {$[0.34]$} & {$[0.50]$} & {$[0.26]$} & {$[0.36]$} & {$[0.53]$} & [0.29] \\
\hline $\bar{R}^{2}$ & 0.20 & 0.03 & 0.14 & 0.21 & 0.12 & 0.16 \\
\hline $\mathrm{N}$ & 469 & 469 & 469 & 469 & 469 & 469 \\
\hline \multicolumn{7}{|l|}{ First-stage estimation } \\
\hline $\bar{R}^{2}$ & 0.78 & 0.78 & 0.78 & 0.77 & 0.77 & 0.77 \\
\hline Partial $\bar{R}^{2}$ & 0.49 & 0.49 & 0.49 & 0.51 & 0.51 & 0.51 \\
\hline $\begin{array}{l}\text { F-value } \\
\text { (p-value) }\end{array}$ & $\begin{array}{l}50.13 \\
(0.00)\end{array}$ & $\begin{array}{l}50.13 \\
(0.00)\end{array}$ & $\begin{array}{l}50.13 \\
(0.00)\end{array}$ & $\begin{array}{l}53.43 \\
(0.00)\end{array}$ & $\begin{array}{l}53.43 \\
(0.00)\end{array}$ & $\begin{array}{l}53.43 \\
(0.00)\end{array}$ \\
\hline Excluded instruments & \multicolumn{6}{|c|}{ Lag of STUDYCOST, MIGRATION, ELICOS, VET, SCHOOL } \\
\hline
\end{tabular}

Notes: AustRGDP and AustRGDP ${ }^{2}$ respectively refer to (PPP-adjusted) Australian GDP per capita in natural logarithm and its square. Country-fixed effects are included. Constants are not reported.

The estimated elasticities of Enrolment for total, primary and manufacturing import shares in [4]-[6] are 0.46, 0.35 and 0.46 respectively, which are more uniform than for exports. Taking the results in Tables 4 and 5, we conclude that study in Australia promotes (future) bilateral trade between Australia and student source countries.

\section{Additional analysis for the demand for international higher education}

\section{Common language}

Our estimates show that international student flows for higher education are positively related to the numbers who have previously used other pathways. Does this effect hold equally for students from both English and non-English speaking backgrounds? Students with an educational background in English are more likely to be familiar with the Australian culture 
and customs as well as the language, and this familiarity reduces the barriers to studying in Australia at the same time as it reduces the signalling and other benefits. To investigate further, we add Comlang and its interaction with the three pathways to the independent variables in equation (1). The results are in Table 6. The positive and statistically significant coefficient on Comlang indicates that students from other English-speaking countries are more likely to study in Australia, other things equal, and is a common finding in the literature (e.g. Beine et al., 2011; Perkins and Neumayer, 2014; Zheng, 2014 ). The estimated coefficients on the interactions between Comlang and ELICOS and VET are not significant suggesting that an English speaking background has no discernible effect on the use of these pathways. However, the negative and significant sign of Comlang*School, indicates that students from countries where English is not an official language are more likely to use this pathway.

In a similar vein, we include the interaction between common language and migrant stock (Comlang*MIGRATION). The negative and significant results in Table 6 indicate that migrant network effects are smaller for students from countries where English is an official language, thereby supporting H3A. They remain positive, however.

Table 6 Common language effect on Enrolments

\begin{tabular}{|c|c|c|c|c|}
\hline & [1] & [2] & [3] & {$[4]$} \\
\hline \multirow[t]{2}{*}{ Comlang } & $0.721 * * *$ & $0.444 * * *$ & $0.542 * * *$ & $1.083^{* * *}$ \\
\hline & {$[0.12]$} & [0.17] & [0.19] & {$[0.22]$} \\
\hline \multirow{2}{*}{ Comlang*School } & $-0.132^{* * *}$ & & & \\
\hline & {$[0.04]$} & & & \\
\hline \multirow[t]{2}{*}{ Comlang*ELICOS } & & -0.016 & & \\
\hline & & {$[0.05]$} & & \\
\hline \multirow[t]{2}{*}{ Comlang*VET } & & & -0.033 & \\
\hline & & & {$[0.04]$} & \\
\hline \multirow[t]{2}{*}{ Comlang *MIGRATION } & & & & $-0.139 * * *$ \\
\hline & & & & {$[0.05]$} \\
\hline \multirow[t]{2}{*}{$R G D P$} & $-0.74 * * *$ & $-0.79 * * *$ & $-0.78 * * *$ & $-0.71 * * *$ \\
\hline & {$[0.13]$} & {$[0.13]$} & {$[0.13]$} & {$[0.13]$} \\
\hline$R G D P^{2}$ & $0.19 * * *$ & $0.20 * * *$ & $0.20 * * *$ & $0.18^{* * *}$ \\
\hline
\end{tabular}




\begin{tabular}{lllll} 
& {$[0.04]$} & {$[0.04]$} & {$[0.04]$} & {$[0.04]$} \\
STUDYCOST & $0.94^{*}$ & 0.87 & 0.88 & 0.86 \\
& {$[0.53]$} & {$[0.54]$} & {$[0.54]$} & {$[0.52]$} \\
MIGRATION & $0.25^{* * *}$ & $0.23^{* * *}$ & $0.24^{* * *}$ & $0.28^{* * *}$ \\
& {$[0.04]$} & {$[0.05]$} & {$[0.05]$} & {$[0.05]$} \\
SCHOOL & $0.35^{* * *}$ & $0.31^{* * *}$ & $0.31^{* * *}$ & $0.32^{* * *}$ \\
& {$[0.04]$} & {$[0.04]$} & {$[0.03]$} & {$[0.03]$} \\
ELICOS & $0.14^{* * *}$ & $0.15^{* * *}$ & $0.14^{* * *}$ & $0.13^{* * *}$ \\
& {$[0.03]$} & {$[0.05]$} & {$[0.03]$} & {$[0.03]$} \\
VET & $0.22^{* * *}$ & $0.23^{* * *}$ & $0.24^{* * *}$ & $0.24^{* * *}$ \\
& {$[0.04]$} & {$[0.05]$} & {$[0.04]$} & {$[0.04]$} \\
& & & & \\
$\bar{R}^{2}$ & 0.73 & 0.72 & 0.72 & 0.73 \\
$\mathrm{~N}$ & 485 & 485 & 485 & 485 \\
BIC & 1222.0 & 1229.0 & 1228.7 & 1221.2 \\
\hline
\end{tabular}

Note: Constants are not shown. English speaking countries are: Bermuda, Cameroon, Canada, HK SAR, Fiji, Gambia, Ghana, India, Ireland, Israel, Jamaica, Jordan, Kenya, Kiribati, Kuwait, Malta, Namibia, New Zealand, Pakistan, Philippines, Qatar, Rwanda, Singapore, South Africa, Swaziland, USA, United Kingdom, Vanuatu, Zambia and Zimbabwe. Country-fixed effects are included.

\section{Global Financial Crisis}

Many of the effects of the global financial crisis (GFC) on the international student flows for tertiary education in Australia would work through our explanatory variables, particularly real income and relative study costs (which take account of exchange rate changes). But it is possible that the GFC had (temporary) structural effects. To investigate these we added GFC0809 and its interactions with our pathways and network externality variables. The results in Table 7 indicate that the GFC itself negatively affected the number of international tertiary students in Australia from all sources, but without moderating the student's use of pathway opportunities. The significant, positive sign on GFC0809*MIGRATION, provides some evidence that international students rely more on the support of local compatriots when the financial climate is difficult.

Table 7 The Effects of the Global Financial Crisis on Enrolments

$$
[1]
$$

$$
\text { [2] }
$$

[3]

[4]

[5]

[6] 


\begin{tabular}{|c|c|c|c|c|c|c|}
\hline \multirow[t]{2}{*}{ GFC0809 } & $-0.16 *$ & $-0.16^{*}$ & $-0.17^{*}$ & $-0.17^{*}$ & $-0.18^{*}$ & $-0.28^{* *}$ \\
\hline & {$[0.09]$} & {$[0.09]$} & {$[0.10]$} & {$[0.10]$} & {$[0.10]$} & {$[0.12]$} \\
\hline \multirow[t]{2}{*}{ GFCO809*SCHOOL } & & 0.00 & & & -0.05 & -0.04 \\
\hline & & {$[0.03]$} & & & {$[0.05]$} & {$[0.05]$} \\
\hline \multirow[t]{2}{*}{ GFCO809*ELICOS } & & & 0.01 & & 0.05 & 0.07 \\
\hline & & & {$[0.03]$} & & {$[0.07]$} & {$[0.07]$} \\
\hline \multirow[t]{2}{*}{ GFC0809*VET } & & & & 0.00 & -0.18 & $-0.19 *$ \\
\hline & & & & {$[0.02]$} & {$[0.12]$} & {$[0.10]$} \\
\hline \multirow[t]{2}{*}{ GFCO809*MIGRATION } & & & & & $0.17^{* *}$ & $0.17^{* *}$ \\
\hline & & & & & {$[0.09]$} & {$[0.08]$} \\
\hline \multirow[t]{2}{*}{ Lowincome } & & & & & & 0.20 \\
\hline & & & & & & {$[0.15]$} \\
\hline \multirow[t]{2}{*}{ GFC0809*Lowincome } & & & & & & $0.35^{*}$ \\
\hline & & & & & & {$[0.21]$} \\
\hline \multirow[t]{2}{*}{$R G D P$} & $-0.86 * * *$ & $-0.86^{* * *}$ & $-0.86 * * *$ & $-0.86 * * *$ & $-0.88^{* * *}$ & $-0.84 * * *$ \\
\hline & {$[0.14]$} & {$[0.14]$} & {$[0.14]$} & {$[0.14]$} & {$[0.13]$} & {$[0.13]$} \\
\hline \multirow[t]{2}{*}{$R G D P^{2}$} & $0.22 * * *$ & $0.22^{* * *}$ & $0.22^{* * *}$ & $0.22^{* * *}$ & $0.22^{* * *}$ & $0.24^{* * *}$ \\
\hline & {$[0.04]$} & {$[0.04]$} & {$[0.04]$} & {$[0.04]$} & {$[0.04]$} & {$[0.04]$} \\
\hline \multirow[t]{2}{*}{ STUDYCOSTS } & $1.23^{* * *}$ & $1.24^{* * *}$ & $1.25^{* * *}$ & $1.25^{* * *}$ & $1.28 * * *$ & $1.27^{* * *}$ \\
\hline & {$[0.26]$} & {$[0.27]$} & {$[0.28]$} & {$[0.28]$} & {$[0.28]$} & {$[0.28]$} \\
\hline \multirow[t]{2}{*}{ MIGRATION } & $0.26^{* * *}$ & $0.26^{* * *}$ & $0.26 * * *$ & $0.25^{* * *}$ & $0.28^{* * *}$ & $0.28 * * *$ \\
\hline & {$[0.04]$} & {$[0.04]$} & {$[0.04]$} & {$[0.04]$} & {$[0.05]$} & {$[0.05]$} \\
\hline \multirow[t]{2}{*}{ SCHOOL } & $0.32^{* * *}$ & $0.32^{* * *}$ & $0.32 * * *$ & $0.32^{* * *}$ & $0.33^{* * *}$ & $0.33^{* * *}$ \\
\hline & {$[0.04]$} & {$[0.04]$} & {$[0.04]$} & {$[0.04]$} & {$[0.04]$} & {$[0.04]$} \\
\hline \multirow[t]{2}{*}{ ELICOS } & $0.10^{* * *}$ & $0.10^{* * *}$ & $0.10^{* * *}$ & $0.10^{* * *}$ & $0.09 * * *$ & $0.09 * * *$ \\
\hline & {$[0.03]$} & {$[0.03]$} & {$[0.03]$} & {$[0.03]$} & {$[0.03]$} & {$[0.03]$} \\
\hline \multirow[t]{2}{*}{$V E T$} & $0.26^{* * *}$ & $0.26^{* * *}$ & $0.26^{* * *}$ & $0.25^{* * *}$ & $0.28^{* * *}$ & $0.28^{* * *}$ \\
\hline & {$[0.04]$} & {$[0.04]$} & {$[0.04]$} & {$[0.04]$} & {$[0.05]$} & {$[0.05]$} \\
\hline $\bar{R}^{2}$ & 0.72 & 0.72 & 0.72 & 0.72 & 0.72 & 0.72 \\
\hline$N$ & 485 & 485 & 485 & 485 & 485 & 485 \\
\hline bic & 1228.03 & 1234.21 & 1234.16 & 1234.18 & 1246.83 & 1253.11 \\
\hline
\end{tabular}

Note: Constants are not shown. Country-fixed effects are included

Finally, we examine the argument that the impact of the GFC was weaker for low income economies, because they were less directly affected by the crisis, by adding Lowincome, and its interaction with GFC0809. The positive and significant estimated coefficient on the interaction term in [6] indicates that the negative impact of the GFC was stronger for enrolments from high income countries than from low income economies. 


\section{SUMMARY AND CONCLUSIONS}

We began by noting that international tertiary education is one way in which individuals can acquire the international human capital important for success in the global economy. The research literature exploring the factors that determine the bilateral flows of international university students is composed of two, complementary types of studies. The first involves qualitative analysis of survey data at the individual student level and students at Australian universities or their overseas branch campuses have been well represented in this work. The second involves econometric analysis of published data where there seems to have been no previous analysis of Australian data.

Our first goal was to empirically investigate the factors determining international student flows for Australian higher education. The results confirmed the importance of source financial ability and Australia's competitiveness in this market. The opportunities provided by existing migrant-networks and through other education pathways were also significant. Other things equal, international student flows are higher in source countries where English is an official language, but this seems to attenuate the positive effects of the secondary school pathway and the migration-network. The Global Financial Crisis reduced international student flows, but its impact was attenuated by migration networks and for low income countries.

Our second goal was to explore the links between the international student inflows to Australia and Australia's trade with the source country. Our instrumental variables estimates suggested that international student inflows implied greater integration of bilateral goods markets in the future as the international human capital theory suggests. The source country’s share in Australia’s total, primary and manufacturing exports and imports were all increased, after a lag, by higher Australian university enrolments of its students.

Our results have implications for the strategies of both government and universities wishing to attract international students. Firstly, the nonlinearity in the estimated relationship 
between international student flows and source country real income per capita implies that growth in a relatively poor country, would see a declining flow of students, other things equal, while growth in a relatively richer country would see an increased flow. Whether this decline is due to an improvement in source country tertiary institutions, a reduced incentive to migrate or simply a switch to non-Australian hosts, only further investigation will reveal. But it does suggest that growing but relatively poor countries may not be the best targets of universities' marketing efforts, despite their attractiveness as 'emerging markets'. The supply of international students from wealthier countries appears to be more income elastic, so that fastgrowing middle-income countries may make better marketing targets.

Secondly, our findings reinforce the significance of the other pathways (ELICOS, Schools and even VET) for university study by international students. These pathways provide 'spillover' benefits in the form of increased exports of university education services, in addition to the direct fees they themselves attract. Policy and other barriers to any of these pathways may have unintended consequences for tertiary enrolments by international students.

Thirdly, the significance of source country migrant stocks for international student enrolments, particularly where English is not their first language, suggests that increased immigrant flows will result in increased future exports of tertiary education services to the same source country. Since immigrants tend to cluster in large cities, it seems likely that it will be the metropolitan universities that will benefit most from these increased flows.

Finally, if, as our results appear to show, current international student enrolments induce increased bilateral trade flows in the future, then part of the associated gains from trade should be recognised as a benefit flowing from the current provision of international education. Current university education exports contain the seeds of future exports and imports in all sectors of the economy. At the same time that the students are investing in their education, the host country is investing in their trade-creating potential. 
While an Australian case study of the international demand for tertiary education can provide useful insights, an extended study using panel data on the major international tertiary education providers would be beneficial to confirm and extend our findings. Given that universities are becoming more heavily dependent on non-governmental financing and are devoting increased resources to international marketing, it would be useful to know how sensitive international student flows are to relative costs and the perceived 'quality' of a country's tertiary institutions. For this one would need better information on study costs and institutional quality than seems to be currently available. 


\section{REFERENCES}

Agarwal V. B. and D. R. Winkler, 1985 "Foreign demand for United States Higher Education: A Study of developing countries in the Eastern Hemisphere", Economic Development and Cultural Change, 33(3): 623-644

Aguillo, I., J. Bar-Ilan, M. Levene, and J. Ortega, 2010, “Comparing university rankings,' 'Scientometrics, 85 (1): 243-256.

Ahlstrom, D., and G. Bruton, 2006. 'Venture capital in emerging economies: Networks and institutional change.’ Entrepreneurship Theory and Practice, 30(2): 299-320.

Ahmad, S. Z. and F. R. Buchanan, 2015 "Motivation factors in students decision to study at international branch campuses in Malaysia”, Studies in Higher Education, forthcoming.

Ahmad, S. Z. and M Hussain, 2015 “An investigation of the factors determining student destination choice for higher education in the United Arab Emirates”, Studies in Higher Education, forthcoming.

Aleksynska, M. and G. Peri, 2012, 'Isolating the Network Effect of Immigrants on Trade' IZA Discussion Paper No. 6941

Anderson, J E. and E. van Wincoop, 2004. 'Trade costs.' Journal of Economic Literature, 42: 691-751.

Australian Department of Education, 2014 "Study pathways of international students in Australia”, Research Paper 2014/01.

Beine, M., F. Docquier, and C. Ozden, 2015, Dissecting network externalities in international migration, Journal of Demographic Economics, 81: 379-408.

Beine, M. R. Noel and L. Ragot, 2011 "The determinants of international mobility of students" Working Paper, University of Luxemburg. ,

Bessey, D. 2012, “International student migration to Germany”, Empirical Economics, 42:345361.

Cantwell, B. S., G. Luca and J. J. Lee 2009 "Exploring the orientations of international students in Mexico: Differences by region of origin”, Higher Education, 57: 335-354

Carneiro, P., and J. J. Heckman, 2002, 'The evidence on credit constraints in post-secondary schooling,' Economic Journal, 112:989-1018.

Choudaha, R., L. Chang, and Y. Kono, 2013, 'International student mobility trends 2013: Towards responsive recruitment strategies,' Research Report \#4, World Education Service (www.wes.org/RAS). 
Disdier, A-C. and K. Head. 2008. 'The Puzzling Persistence of the Distance Effect on Bilateral Trade,' Review of Economics and Statistics, 90(1): 37-48.

Dreher, A., and P. Poutvaara, 2005, Student flows and migration: An empirical analysis, IZA Discussion Paper \#1612.

Gong, X. and T. Huybers, 2015 'Chinese students and higher education destinations: Findings from a choice experiment’ Australian Journal of Education, 59(2): 196-218.

Gonzalez, C. R., R. B. Mesanza and P. Mariel, 2011, “The antecedents of international student mobility flows: An empirical study on the Erasmus programme” Higher Education, 62(4): 413430.

Keane, M., 2002, 'Financial aid, borrowing constraints and college attendance: Evidence from structural estimates,' American Economic Review, 92:293-297.

Lee K. H. and J. P. Tan 1984, 'The international flow of third level lesser developed country students to developed countries: determinants and implications”, Higher Education, 13(6); 687-707.

Li, M. and M. Bray, 2007 "Cross-border flows of students for higher education: push-pull factors and motivations of mainland Chinese students in Hong Kong and Macau”, Higher Education, 53: 791-818.

Lu, Y., F. T. Mavondo and l. L. Qui 2009 "Factors influencing the choice of overseas study by undergraduate and postgraduate Chinese students” Monash University.

Mazzarol, T. and G. N. Soutar, 2002 “'Push-pull’ factors influencing international student destination choice”, International Journal of Educational Management, 16(2): 82-90.

McMahon, M. 1992 "Higher education in a world market: An historical look at the global context of international study”, Higher Education, 24(4): 465-482.

Naidoo, V. 2007, "Research on the flow of international students to UK universities", Journal of Research in International Education, 6(3): 287-307.

Parsons, C. 2011, Do Migrants Really Foster Trade? The Trade-Migration Nexus, a Panel Approach 1960-2000. GEP Research Paper 11/10.

Pedro, E. and M. Franco 2016 "The importance of networks in the transnational mobility of higher education students; attraction and satisfaction of foreign mobility students at a public university”, Studies in Higher Education, 41(9); 1627-1655.

Perkins, R. and E. Neumayer 2014 "Geographies of educational mobilities: exploring the uneven flows of international students”, The Geographical Journal, 180(3): 246-259.

Pyvis D. and A. Chapman 2007 "Why university students choose an international education: A case study of Malaysia”, International Journal of Educational Development, 27(2): 235-246. 
Rauch, J., 2001. 'Business and social networks in international trade.' Journal of Economic Literature, 39: 1177-1203.

Rose, A., 2007, 'The foreign services and foreign trade: Embassies as export promotion,' The World Economy, 30: 22-38.

Shanka, T., V. Quintal and R. Taylor, 2006, “Factors influencing international students' choice on an education destination - A correspondence analysis”, Journal of Marketing and Higher Education, 15(2): 31-46.

Soo K. T. and C. Elliott, 2010 "Does price matter? Overseas students in UK higher education”, Economics of Education Review, 29; 553-565

Souto-Otero M. and J. Enders, 2015 “international students’ and employers’ use of rankings: a cross-national analysis”, Studies in Higher Education, forthcoming.

Wei, H., 2013 “An empirical study on the determinants of international student mobility: a global perspective’, Higher Education, 66: 105-122.

Wooldridge, J., 2010, Econometric Analysis of Cross Section and Panel Data, The MIT Press, Cambridge.

Zheng, P. 2014 "Antecedents to international student inflows to UK higher education: A comparative analysis”, Journal of Business Research, 67(20: 136-143. 


\section{Appendix A1.}

Calculated Annual Cost of Studying Abroad for International Students (US\$000 pa)

\begin{tabular}{|c|c|c|c|c|c|c|c|c|c|}
\hline Year & \multicolumn{3}{|c|}{ Australia } & \multicolumn{3}{c|}{ UK } & \multicolumn{3}{|c|}{ US } \\
\hline & Fees & CoL & Total & Fees & CoL & Total & Fees & CoL & Total \\
\hline 2001 & 7.13 & 5.06 & 12.19 & 6.87 & 7.59 & 14.46 & 13.46 & 7.96 & 21.42 \\
\hline 2002 & 7.85 & 5.46 & 13.31 & 7.56 & 7.99 & 15.56 & 14.35 & 8.15 & 22.50 \\
\hline 2003 & 9.91 & 6.74 & 16.66 & 8.86 & 8.83 & 17.70 & 15.38 & 8.30 & 23.69 \\
\hline 2004 & 12.01 & 7.78 & 19.79 & 10.40 & 10.03 & 20.44 & 16.39 & 8.57 & 24.96 \\
\hline 2005 & 13.21 & 8.28 & 21.49 & 10.84 & 10.17 & 21.01 & 17.39 & 8.87 & 26.26 \\
\hline 2006 & 13.69 & 8.45 & 22.14 & 11.78 & 10.54 & 22.32 & 18.49 & 9.09 & 27.59 \\
\hline 2007 & 15.86 & 9.68 & 25.54 & 14.54 & 11.72 & 26.26 & 19.52 & 9.34 & 28.86 \\
\hline 2008 & 16.90 & 10.21 & 27.11 & 15.06 & 11.25 & 26.31 & 20.62 & 9.70 & 30.32 \\
\hline 2009 & 16.57 & 9.68 & 26.24 & 13.68 & 9.70 & 23.38 & 21.60 & 9.66 & 31.26 \\
\hline 2010 & 20.34 & 11.54 & 31.89 & 14.22 & 9.90 & 24.12 & 22.43 & 9.83 & 32.26 \\
\hline 2011 & 24.19 & 13.37 & 37.56 & 15.52 & 10.73 & 26.25 & 23.47 & 10.13 & 33.60 \\
\hline 2012 & 25.71 & 13.69 & 39.40 & 16.68 & 10.90 & 27.58 & 24.37 & 10.34 & 34.71 \\
\hline 2013 & 25.38 & 13.14 & 38.52 & 19.29 & 11.03 & 30.33 & 25.23 & 10.48 & 35.71 \\
\hline
\end{tabular}

Notes: 2013 figures from 'Annual cost of studying abroad for international students' HSBC News Release 13/August/2013, which notes that (a) Fees represent the average tuition cost for international students based on the top 10 largest institutions in each relevant country (sourced from individual institution data); and (b) Cost of living sourced from HESA Global Education Rankings 2010 where possible and adjusted to account for inflation and from Expatitsan.co.uk and HSBC Studying Abroad Research (Oct 2012) otherwise. To construct comparable data for 2001-2012 we deflate the Fees by the education cost component of the cost of living index, and the CoL by the full consumer price index, and also take into account changes in exchange rates. Australian data is from the Australian Bureau of Statistics, US data from the US Bureau of Labor Statistics and UK data from the UK Office of National Statistics, respectively. 